\title{
Pola Penyebaran Burung di Kawasan Taman Wisata Alam Wera, Sigi, Sulawesi Tengah, Indonesia
}

\section{Bird Distribution Pattern in Wera Natural Park, Sigi, Central Sulawesi, Indonesia}

\author{
Sultika $^{1 *}$, Annawaty ${ }^{1)}$, Ramadhanil Pitopang ${ }^{1)}$, Mohammad. Ihsan ${ }^{2)}$ \\ ${ }^{1)}$ Jurusan Biologi, Fakultas Matematika dan Ilmu PengetahuanAlam, Universitas Tadulako Kampus Bumi \\ Tadulako Tondo, Palu 94117, Sulawesi Tengah, Indonesia \\ ${ }^{2)}$ Jurusan Kehutanan, Fakultas Kehutanan, Universitas Tadulako \\ Kampus Bumi Tadulako Tondo, Palu 94117, Sulawesi Tengah, Indonesia
}

\begin{abstract}
Avian distribution patterns in Wera Nature Park, Sigi, Central Sulawesi was studied. The Index of Point Abundance (IPA) method was used in this study, in where the observer put at a certain point that has been randomly chosen based on habitat condition from densely vegetation habitat until $200 \mathrm{~m}$ in open habitat. There are 12 birds spesies found in location namely, Colacalia vanikorensis, Colacalia esculenta, Nectarinia jugular, Nectarinia aspasia, Halcyon chloris, Chalcophaps indica, Haliastur indus, Pynonotus aurigaster, Streptocitta albicollis, Dicrurus hottenttotus, Zopterops chloris, Phaenicophaeus calyorhync, Two of the species are endemic to Sulawesi i.e. Streptocitta albicollis and Phaenicophaeus calyorhynchus. The distribution pattern of eigh avian species in Wera Nature Park was clumped while four species can not analyze.
\end{abstract}

Keywords: Birds, distribution patterns, Wera Nature Park, Sulawesi

\begin{abstract}
ABSTRAK
Penelitian ini bertujuan untuk mengetahui "Pola Penyebaran Burung di Kawasan Taman Wisata Alam (TWA) Wera Kecamatan Dolo Barat, Kab. Sigi. Sulawesi Tengah" Metode yang di gunakan yaitu metode Indeks Point of Abundance (IPA) dimana pengamat menempatkan diri pada suatu titik tertentu yang telah dipilih secara acak sesuai dengan kondisi habitat yang rapat sampai dengan $200 \mathrm{~m}$ pada habitat terbuka. Pengamatan dilakukan pada bulan Maret 2016. Dari hasil pengamatan terdapat 12 jenis burung yaitu Walet Polos (Colacalia vanikorensis), Walet Sapi (Colacalia esculenta), Burung Madu Sriganti (Nectarinia jugularis), Burung Madu Hitam (Nectarinia Aspasia), Cekakak Sungai (Halcyon chloris), Delimukan Zamrud (Chalcophaps indica), Elang Bondol (Haliastur Indus), Cucak Kutilang (Pynonotus aurigaster), Blibong Pendeta (Streptocitta albicollis), Srigunting Jambul Rambut (Dicrurus hottenttotus), Kacamata Laut (Zopterops chloris), Kadalan Sulawesi (Phaenicophaeus calyorhync), dan 2 jenis diantaranya merupakan burung endemik Sulawesi yaitu Blibong Pendeta (Streptocitta albicollis) dan Kadalan Sulawesi (Phaenicophaeus calyorhynchus). Dari dua belas jenis burung ini, delapan jenis memiliki pola penyebaran mengelompok dan empat jenis lainnya tidak teranalisis.
\end{abstract}

Kata kunci: Burung, Pola penyebaran, Taman Wisata Alam Wera, Sulawesi 


\section{LATAR BELAKANG}

Wilayah Indonesia ditempati oleh 1.598 jenis burung, yang sebagian diantaranya bersifat menetap dan sebagian lagi bersifat migran. Faktor yang mempengaruhi penyebaran burung adalah faktor kimia, habitat dan faktor fisik serta kemampuan pemencaran, perilaku dan ada tidaknya spesies lain (Celebes Bird Club, 2006). Persebaran dan keanekaragaman burung pada setiap daerah memiliki perbedaan yang dipengaruhi oleh luas habitat, struktur vegetasi, serta tingkat kualitas di masing-masing wilayah (Howes et al, 2003).

Salah satu wilayah di Indonesia yang memiliki kekayaan avifauna adalah Sulawesi. Pulau ini terletak di wilayah Wallacea yang secara biogeografis merupakan wilayah perpaduan antara fauna benua Asia dengan Australia. Kekayaan endemisitas avifauna pulau ini masih belum banyak diketahui dengan baik (Holmes \& Phillips, 1989 ; Coates et al., 1996).

Menurut Mallo (1996), pada daratan Sulawesi terdapat 267 jenis burung dan sekitar $71 \%$ di antaranya adalah endemik di subkawasan Sulawesi dan Kepulauan Sula. Salah satu wilayah di Sulawesi yang memiliki kenekaragaman jenis burung yang cukup tinggi adalah Lembah Palu., Tercatat \pm 187 jenis burung yang terdapat di wilayah tersebut. Lembah Palu memiliki vegetasi hutan musim yang diakibatkan karena frekuensi curah hujan yang sangat rendah dibanding dengan semua wilayah di Indonesia, sehingga komposisi jenis burungnya juga sangat khas dan berbeda dengan wilayah lainnya.

Salah satu wilayah di lembah Palu yaitu Taman Wisata Alam (TWA) Wera yang memiliki keanekaragaman jenis burung cukup banyak. Tetapi berdasarkan informasi dari BKSDA Sulawesi Tengah (2010) dan instansi terkait, laporan mengenai pola penyebaran burung di kawasan tersebut masih kurang sehingga perlu dilakukan penelitian untuk mengetahui bagaimana pola penyebaran burung di wilayah tersebut.

\section{BAHAN DAN METODE}

\section{Waktu dan Tempat}

Penelitian ini dilaksanakan pada bulan Maret 2016 dan bertempat di TWA Wera Kecamatan Dolo Barat Kabupaten Sigi. Peta lokasi penelitian disajikan pada Gambar 1.

\section{Alat dan Bahan}

Alat yang digunakan dalam penelitian ini yaitu peta binokuler pentax $(10 \times 40)$ untuk melihat objek yang jauh dari jangkauan, tally sheet untuk mencatat data burung yang diamati, GPS (Global Position System) menentukan titik koordinat lokasi, pita meter untuk mengukur jarak titik penelitian, kamera untuk mengambil dokumentasi, jam tangan untuk 
mengetahui waktu, buku panduan burungburung kawasan Walacea (Coates et al, 2000), tali rafia menandai titik pengamatan, alat tulis menulis untuk mencatat hasil pengamatan

\section{Metodologi}

Metode yang digunakan pada penelitian ini yaitu metode Indeks Point of Abundance (IPA). Pada metode ini pengamat menempatkan diri pada suatu titik tertentu yang telah dipilih secara acak maupun sistematik sesuai dengan kondisi habitat yang rapat sampai dengan $200 \mathrm{~m}$ pada habitat terbuka dengan jarak pengamat $50 \mathrm{~m}$ sesuai dengan habitat dan jarak pandang.

\section{Analisis Data}

\section{Komposisi Jenis}

Komposisi jenis burung dapat diketahui dengan cara memasukkan semua data yang diperoleh di lapangan ke dalam Tabel 1 sehingga terlihat pada setiap titik pengamatan keberadaan jenis burung (Tebisi, 2013).

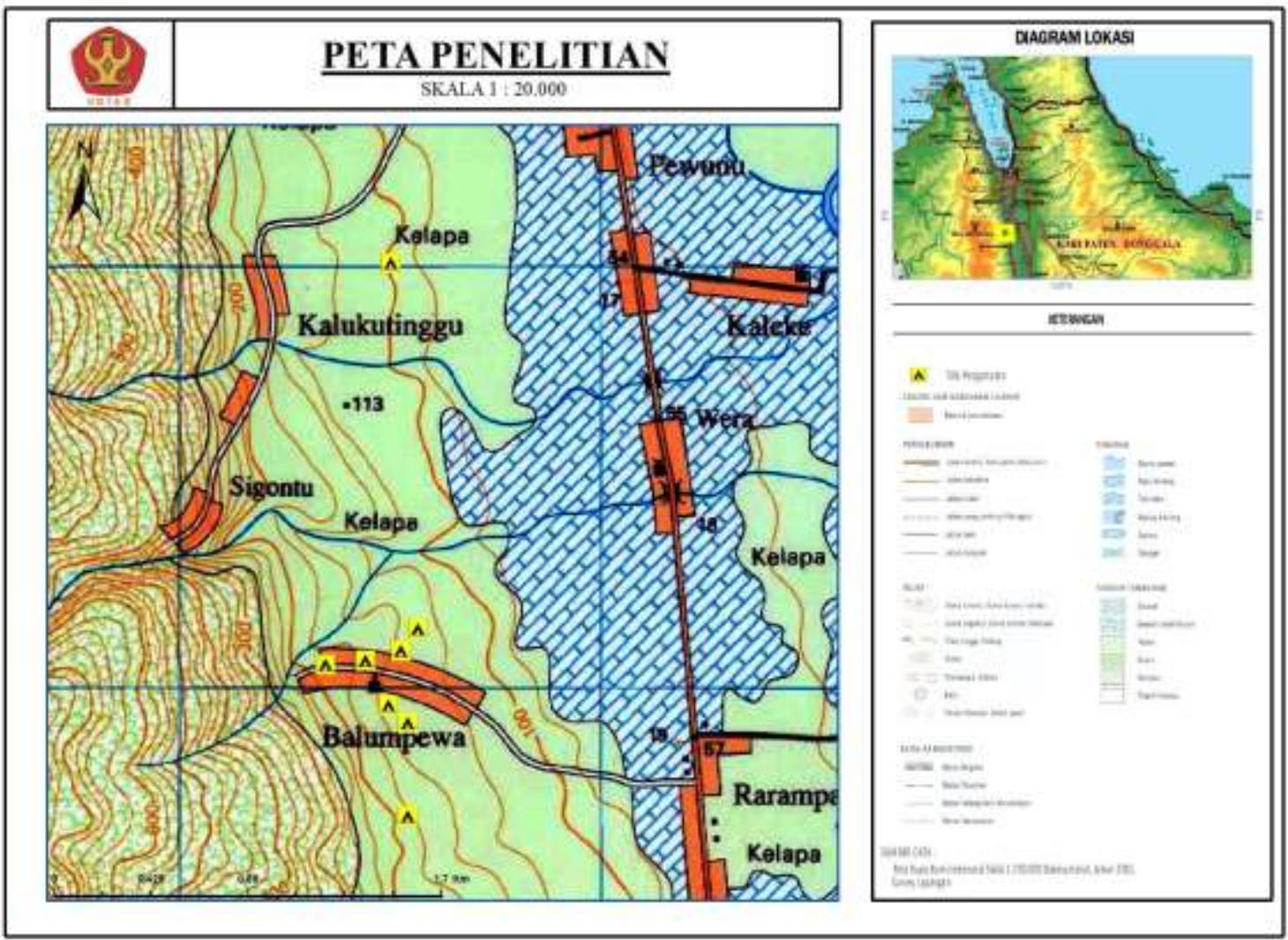

Gambar 1. Peta Taman Wisata Alam Wera skala 1:20.000 (Peta Rupa Bumi Indonesia, 2001).

\section{Pola Penyebaran}

Pola sebaran burung dianalisis dengan menggunakan Indeks Morisita $(I \delta)$. Indeks Morisita (IS) banyak digunakan oleh peneliti karena selain memiliki sebaran penarikan contoh juga memiliki indeks turunannya yang dapat di gunakan untuk menentukan pola sebaran, yakni indeks pemencaran morisita yang distandarkan (standardized Morisita 
indeks of dispersion) yang dinotasikan dengan $I_{p}$ (Krebs, 1989). Kemudian Krebs (1989) menjelaskan tahapan penghitungan dengan menggunakan metode Indeks Morisita $(I \delta)$ adalah sebagai berikut:

$$
\begin{aligned}
& \mathrm{I} \delta=\mathrm{n}\left[\frac{\Sigma x^{2}-\Sigma x}{(\Sigma x)^{2}-\Sigma x}\right] \\
& \mathrm{Mu}=\frac{x^{2} 0,975 ; d f^{\prime}-n+\Sigma x i}{(\Sigma x i)-1} \\
& \mathrm{Mc}=\frac{x^{2} 0,025 ; d f^{-n+\Sigma x i}}{(\Sigma x i)-1}
\end{aligned}
$$

Keterangan:

I $\delta \quad$ : Indeks morisita

$\mathrm{Mu} \quad$ : Indeks pola sebaran seragam

Mc : Indeks pola sebaran agregatif

n : Ukuran contoh

xi : Jumlah individu dalam unit contoh ke-i

Kaidah keputusan untuk menentukan bentuk pola sebaran organisme yang diamati adalah sebagai berikut:

Bila nilai $\mathrm{I} \delta \geq \mathrm{Mc} \geq 1.0$, maka $I_{p}$ di hitung dengan menggunakan persamaan:

$$
I_{p}=0,5+0,5\left(\frac{I \delta-M c}{n-M c}\right)
$$

$$
I_{p}=0,5\left(\frac{I \delta-1}{M c-1}\right)
$$

Bila nilai $1,0>I \delta>\mathrm{Mu}$, maka $I_{p}$ di hitung dengan menggunakan persamaan:

$$
I_{p}=0,5\left(\frac{I \delta-1}{M u-1}\right)
$$

Bila nilai $1,0>\mathrm{Mu}>I \delta$, maka $I_{p} \mathrm{di}$ hitung dengan menggunakan persamaan:

$$
I_{p}=-0,5+0,5\left(\frac{I \delta-M u}{M u}\right)
$$

Bila pada selang kepercayaan $95 \%$ nilai $I_{p}$ :

$I_{p}<0$, maka pola sebaran adalah seragam (uniform)

$I_{p}=0$, maka pola sebaran adalah acak (random)

$$
I_{p}>0 \text {, maka pola sebaran }
$$

bergerombol (clumped)

\section{HASIL DAN PEMBAHASAN}

\section{Komposisi Jenis}

Dari hasil pengamatan yang dilakukan di lapangan, ditemukan sebanyak 16 jenis burung yang termasuk dalam 10 famili (Tabel 1).

Bila nilai $\mathrm{Mc}>I \delta \geq 1.0$, maka $I_{p}$ di hitung dengan menggunakan persamaan:

Tabel 1. Komposisi Jenis Burung di TWA Wera

\begin{tabular}{lllllll}
\hline No. & \multicolumn{1}{c}{ Nama Indonesia } & \multicolumn{1}{c}{ Nama Latin } & Nama Lokal & Famili & Jumlah & Ket \\
\hline 1 & Walet Polos & Colacalia vanikorensis & Balolae & Apodidae & 53 & $\mathrm{R}$ \\
2 & Walet Sapi & Colacalia esculenta & Balolae & Apodidae & 37 & $\mathrm{R}$ \\
3 & Burung Madu Sriganti & Nectarinia jugularis & Cui & Nectariniidae & 7 & $\mathrm{R}$ \\
4 & Burung Madu Hitam & Nectarinia aspasia & Cui & Nectariniidae & 1 & $\mathrm{R}$ \\
5 & Cekakak Sungai & Halcyon chloris & Tenggo & Alcedinidae & 2 & $\mathrm{R}$ \\
6 & Delimukan Zamrud & Chalcophaps indica & Peronjo & Columbidae & 1 & $\mathrm{R}$ \\
7 & Elang Bondol & Haliastur indus & Love & Accipitridae & 1 & $\mathrm{R}$ \\
8 & Cucak Kutilang & Pynonotus aurigaster & Kutilang & Pycnonotidae & 2 & $\mathrm{R}$ \\
9 & Blibong Pendeta & Streptocitta albicollis & Soulayo & Sturnidae & 2 & $\mathrm{R} / \mathrm{E}$ \\
10 & Srigunting Jambul Rambut & Dicrurus hottenttotus & Lantaki & Dicruridae & 1 & $\mathrm{R}$ \\
11 & Kacamata Laut & Zopterops chloris & Oli & Zosteropidae & 4 & $\mathrm{R}$ \\
12 & Kadalan Sulawesi & Phaenicophaeus & Teteka & Cuculidae & 3 & $\mathrm{R} / \mathrm{E}$ \\
\hline
\end{tabular}

Keterangan:
E : Endemik
$\mathrm{R}$ : Resident (penetap)

Pola Penyebaran Burung di Kawasan Taman Wisata Alam Wera, Sigi, Sulawesi Tengah, Indonesia 
Berdasarkan Tabel 1 di atas, terdapat 2 jenis burung endemik Sulawesi yaitu: Kadalan Sulawesi (Phaenicophaeus calyorhinchus) dan Blibong pendeta (Streptocitta albicollis). Famili yang mempunyai jumlah jenis lebih dari satu, yaitu famili Apodidae dan famili Nectarinidae. Famili Apodidae meliputi wallet polos dan wallet sapi. Sedangkan famili Nectarinidae meliputi jenis burung madu sriganti dan burung madu hitam. Sisanya pada sebanyak 8 famili, hanya ditemukan 1 jenis burung.

Secara keseluruhan, berdasarkan jumlah kelimpahan individu terdapat dua jenis yang mempunyai jumlah individu yang paling banyak yaitu Walet Polos
(Collocalia Vanikorensis), 53 individu dan Walet Sapi (Collocalia esculenta), 37 individu, dan sebanyak tiga jenis yang mempunyai jumlah individu paling sedikit yaitu: burung madu hitam, delimukan zamrud, elang bondol dan srigunting jambul rambut yang masing-masing hanya ditemukan 1 individu. Jenis burung lainnya hanya mempunyai kelimpahan individu kurang dari 10 individu.

\section{Pola Penyebaran}

Pola penyebaran burung pada penelitian ini di analisis dengan menggunakan Indeks Morisita (I $\delta$ ). Pola penyebaran burung di TWA Wera di sajikan pada Tabel 2 berikut.

Tabel 2 Pola Penyebaran Burung di TWA Wera

\begin{tabular}{cllll}
\hline No. & \multicolumn{1}{c}{ Jenis Burung } & \multicolumn{1}{c}{ Nama Latin } & \multicolumn{1}{c}{ Famili } & Pola Sebaran \\
\hline 1. & Cekakak Sungai & Halcyon chloris & Alcedinidae & Mengelompok \\
2. & Kacamata Laut & Zopterops chloris & Zosteropidae & Mengelompok \\
3. Burung Madu Sriganti & Nectarinia jugularis & Nectariniidae & Mengelompok \\
4. Kadalan Sulawesi & Phaenicophaeus calyorhynchus & Cuculidae & Mengelompok \\
5. Cucak Kutilang & Pynonotus aurigaster & Pycnonotidae & Mengelompok \\
6. Delimukan Zamrud & Chalcophaps indica & Columbidae & Tidak teranalisis \\
7. & Elang Bondol & Haliastur Indus & Accipitridae & Tidak teranalisis \\
8. Burung Madu Hitam & Nectarinia Aspasia & Nectariniidae & Tidak teranalisis \\
9. & Blibong Pendeta & Streptocitta albicollis & Sturnidae & Mengelompok \\
10. & Srigunting Jambul Rambut & Dicrurus hottenttotus & Dicruridae & Tidak teranalisis \\
11. & Walet Sapi & Colacalia esculenta & Apodidae & Mengelompok \\
12. & Walet Polos & Colacalia vanikorensis & Apodidae & Mengelompok \\
\hline
\end{tabular}

Berdasarkan Tabel 2 dapat dilihat bahwa dari 12 jenis burung, terdapat 8 jenis yang pola penyebarannya berkelompok dan 4 jenis lainnya tidak 
dapat dianalisis hal tersebut disebabkan oleh kelimpahan individu jenis burung tersebut hanya 1 individu.

Pola penyebaran mengelompok pada masing-masing jenis burung ditandai dengan banyaknya individu suatu jenis yang dijumpai. Hal tersebut dapat dilihat pada distribusi masing-masing individu pada plot pengamatan, seperti pada Tabel 3.

Tabel 3 Distribusi individu setiap spesies pada masing-masing plot

\begin{tabular}{|c|c|c|c|c|c|c|c|c|c|}
\hline \multirow{2}{*}{ No. } & \multirow{2}{*}{ Nama Indonesia } & \multicolumn{8}{|c|}{ Jumlah Individu di temukan pada plot ke : } \\
\hline & & 1 & 2 & 3 & 4 & 5 & 6 & 7 & 8 \\
\hline 1 & Cekakak Sungai & 1 & 0 & 1 & 0 & 0 & 0 & 0 & 0 \\
\hline 2 & Kacamata Laut & 0 & 0 & 1 & 0 & 3 & 0 & 0 & 0 \\
\hline 3 & Burung Madu Sriganti & 1 & 3 & 0 & 1 & 1 & 0 & 0 & 0 \\
\hline 4 & Kadalan Sulawesi & 1 & 0 & 1 & 0 & 0 & 0 & 0 & 0 \\
\hline 5 & Cucak Kutilang & 0 & 0 & 0 & 0 & 2 & 0 & 0 & 0 \\
\hline 6 & Blibong Pendeta & 0 & 0 & 0 & 0 & 0 & 0 & 0 & 2 \\
\hline 7 & Walet Sapi & 2 & 0 & 0 & 0 & 0 & 0 & 15 & 10 \\
\hline 8 & Walet Polos & 3 & 0 & 0 & 1 & 2 & 3 & 15 & 23 \\
\hline 9 & $\begin{array}{l}\text { Srigunting Jambul } \\
\text { Rambut }\end{array}$ & 0 & 0 & 0 & 0 & 0 & 1 & 0 & 0 \\
\hline 10 & Burung Madu Hitam & 0 & 1 & 0 & 0 & 0 & 0 & 0 & 0 \\
\hline 11 & Delimukan Zamrud & 0 & 0 & 0 & 1 & 0 & 0 & 0 & 0 \\
\hline 12 & Elang Bondol & 0 & 0 & 0 & 0 & 0 & 0 & 0 & 1 \\
\hline
\end{tabular}

Dari Tabel 3 diketahui bahwa distribusi masing-masing jenis-jenis burung yang ada sebagian besar hanya menempati dua plot, kecuali burung madu sriganti menempati 4 plot, wallet sapi 3 plot dan wallet polos 6 plot. Sedangkan 4 jenis hanya menempati satu plot.
Menurut Odum (1971), bahwa salah satu faktor yang mempengaruhi pola penyebaran berkelompok bagi organisme di alam tergantung pada ketersediaan makanan. Selengkapnya mengenai sumber pakan yang dijumpai dapat dilihat pada Tabel 4. 
Tabel 4 Sumber pakan

\begin{tabular}{|c|c|c|c|}
\hline No. & Jenis Burung & Famili & Makanan* \\
\hline 1. & $\begin{array}{l}\text { Cekakak Sungai (Halcyon } \\
\text { chloris) }\end{array}$ & Alcedinidae & $\begin{array}{l}\text { Kadal, serangga besar, katak } \\
\text { ulat, cacing }\end{array}$ \\
\hline 2. & $\begin{array}{l}\text { Kacamata Laut (Zopterops } \\
\text { chloris) }\end{array}$ & Zosteropidae & Serangga, buah2 kecil, nectar \\
\hline 3. & $\begin{array}{l}\text { Burung Madu Sriganti } \\
\text { (Nectarinia jugularis) }\end{array}$ & Nectariniidae & Nektar, serangga \\
\hline 4. & $\begin{array}{l}\text { Kadalan Sulawesi } \\
\text { (Phaenicophaeus } \\
\text { calyorhynchus) }\end{array}$ & Cuculidae & $\begin{array}{l}\text { Ulat, laba-laba, belalang, } \\
\text { serangga lainnya }\end{array}$ \\
\hline 5. & $\begin{array}{l}\text { Cucak Kutilang (Pynonotus } \\
\text { aurigaster) }\end{array}$ & Pycnonotidae & Buah-buah kecil dan serangga \\
\hline 6. & $\begin{array}{l}\text { Blibong Pendeta (Streptocitta } \\
\text { albicollis) }\end{array}$ & Sturnidae & Buah-buahan dan invertebrate \\
\hline 7. & $\begin{array}{l}\text { Walet Sapi (Colacalia } \\
\text { esculenta) }\end{array}$ & Apodidae & Serangga \\
\hline 8. & $\begin{array}{l}\text { Walet Polos (Colacalia } \\
\text { vanikorensis) }\end{array}$ & Apodidae & Serangga \\
\hline 9. & $\begin{array}{l}\text { Delimukan Zamrud } \\
\text { (Chalcophaps indica) }\end{array}$ & Columbidae & Buah pada bagian tajuk \\
\hline 10. & Elang Bondol (Haliantur indus) & Accipitridae & Vertebrata dan Invertebrata \\
\hline 11. & $\begin{array}{l}\text { Burung Madu Hitam (Nectarinia } \\
\text { aspasia) }\end{array}$ & Nectariniidae & Nektar dan serangga \\
\hline 12. & $\begin{array}{l}\text { Srigunting Jambul Rambut } \\
\text { (Dicrurus hottenttotus) }\end{array}$ & Dicruridae & Serangga di atas tajuk \\
\hline
\end{tabular}

Sumber: John Mac Kinnon 1993.

Berdasarkan Tabel 4 dapat dilihat bahwa jenis burung pemakan serangga lebih banyak dibandingkan jenis burung pemakan buah-buahan, nektar, vertebrata dan invertebrata.

\section{Pembahasan}

Dari hasil penelitian ini diketahui jenis-jenis burung yang mempunyai jumlah individu terbesar dan terkecil, disebabkan oleh pola hidup. Jenis burung yang mempunyai jumlah individu terbesar mempunyai pola hidup berkelompok hal tersebut dapat dilihat dari jumlah kelimpahan individu yang besar. Selain pola hidup, jenis yang termasuk kategori ini pada saat penelitian mempunyai jumlah pakan yang melimpah. Sedangkan jenis yang mempunyai jumlah individu terkecil disebabkan oleh pola hidup soliter dan pakannya tidak melimpah pada saat penelitian.

Dua jenis burung wallet yang mempunyai jumlah individu terbanyak, merupakan jenis burung yang mengkonsumsi serangga sebagai sumber pakannya (Mac Kinnon 1993), sedangkan jenis burung yang mempunyai individu terkecil mengkonsumsi non serangga sebagai sumber pakannya berupa nektar dan vertebrata kecil.

Banyaknya jumlah serangga pada saat penelitian mungkin disebabkan oleh 
tibanya musim hujan. Banyaknya serangga

dilokasi penelitian sejalan dengan pendapat del Rio (2001) bahwa secara alami, sumber makanan berupa serangga merupakan sumber makanan yang tersedia sepanjang waktu, berbeda halnya dengan sumber makanan berupa buah dan nektar yang dipengaruhi oleh waktu (musim berbuah). Menurut Wong (1986), kelimpahan serangga lebih stabil dibandingkan dengan kelimpahan buah dan nektar, sehingga populasi burung pemakan serangga relatif lebih stabil dibandingkan dengan pemakan buah atau nektar.

Pola penyebaran merupakan salah satu ciri khas dari setiap organisme di suatu habitat. Organisme dalam populasi dapat tersebar dalam bentuk-bentuk umum yang terdiri dari tiga macam yaitu penyebaran berkelompok, acak dan merata (Indriyanto, 2008).

Burung merupakan jenis hewan yang mempunyai kemampuan mobilitas yang tinggi sehingga penyebarannya di dunia sangat luas (Windharti dkk, 2013). Penyebaran jenis-jenis burung sangat dipengaruhi oleh kesesuaian tempat hidup, meliputi adaptasi burung terhadap lingkungan, kompetisi, strata vegetasi, ketersediaan pakan dan seleksi alam (Peterson, 1995).

Pola sebaran yang bersifat mengelompok ini ditandai dengan jumlah individu jenis-jenis burung yang dijumpai dibeberapa tempat. Hal ini menunjukkan sebagian besar jenis burung yang didapatkan merupakan jenis burung yang hidupnya suka mengelompok. Selain hal tersebut, pola penyebaran mengelompok juga ditentukan oleh kelimpahan individu dari suatu jenis burung. Hal tersebut dapat dilihat dari perbandingan jenis burung cucak kutilang yang hanya menempati satu plot dengan kelimpahan individu sebanyak 2 individu, dibandingkan dengan 4 jenis lain yang tidak teranalisis, yang juga menempati satu plot dengan kelimpahan individu sebanyak 1 individu.

Perilaku mengelompok diduga disebabkan oleh faktor sumber pakan dari jenis-jenis burung yang dijumpai. Sebanyak 7 jenis burung mengkonsumsi serangga sebagai sumber pakannya, baik sebagai sumber pakan utama maupun sebagai sumber pakan alternative. Sedangkan 1 jenis lainnya mengkonsumsi buah-buahan dan serangga sebagai sumber pakannya.

Secara umum serangga terdapat pada semua tempat di TWA Wera, namun keberadaan di semua tempat tersebut tidak menjadikan burung pemakan serangga dapat dijumpai di semua tempat. Hasil analisis data yang menunjukkan bahwa semua jenis burung yang merupakan pemakan serangga hanya mengelompok pada tempat atau plot tertentu. Hal tersebut 
disebabkan pada lokasi penelitian serangga terkonsentrasi dengan jumlah banyak di tempat-tempat tertentu saja. Hal tersebut dapat dilihat pada burung wallet polos dan wallet sapi yang merupakan pemakan serangga. Kedua jenis burung tersebut dijumpai pada daerah hutan yang terdapat pohon besar seperti Ficus sp. Kedua jenis tersebut tidak dijumpai pada daerah terbuka.

Pada penelitian ini sebagian besar jenis burung yang ditemukan merupakan jenis burung yang pola hidupnya mengelompok, selain itu diduga disebabkan banyaknya ketersediaan sumber makanan dan kondisi tipe habitat yang cocok bagi kehidupan jenis-jenis burung tersebut. Menurut Ludwig dan Reynolds (1988), pola sebaran mengelompok dapat disebabkan oleh sifat jenis burung yang bergerombol (gregorius) atau adanya keragaman (heterogenity) habitat sehingga terjadi pengelompokan di tempat terdapat makanan dan lainnya. Menurut Peterson (1980) penyebaran jenis-jenis burung sangat dipengaruhi oleh kesesuaian tempat hidupnya, kompetisi dan beberapa faktor lainnya.

Menurut Tarumingkeng (1994), pola penyebaran merupakan strategi individu maupun kelompok organisme untuk mempertahankan kelangsungan hidupnya. Kondisi habitat yang meliputi kualitas dan kuantitas sangat menentukan penyebaran populasi satwa liar. Pemilihan habitat ini sesuai dengan pendapat Krebs (1978) yang menyebutkan bahwa tidak adanya jenis tertentu di suatu tempat dapat disebabkan oleh perilaku seleksi habitat (habitat selection).

Berdasarkan hasil observasi, menunjukkan bahwa di TWA Wera telah terjadi gangguan habitat burung. Diantaranya yaitu aktifitas bertani masyarakat setempat dan pungunjung yang tidak menjaga kelestarian kawasan sehingga banyak burung yang sensitif terhadap perubahan habitat dan kehadiran manusia dapat berpindah ke habitat lain dan digantikan oleh jenis burung yang lebih adaptif terhadap perubahan habitat dan gangguan manusia (Ihsan, 2011).

Habitat yang masih baik akan lebih sering dimanfaatkan oleh jenis burung sebagai habitat utamanya karena habitat tersebut burung mendapatkan sumber makanan sekaligus sebagai tempat berlindung dari pemangsa (predator) maupun sebagai tempat berlindung dari cuaca buruk (Nugroho, 2013). Sedangkan Wibowo (2004), mengatakan bahwa burung tidak hanya menggunakan pohon untuk bertengger saja tetapi sebagai tempat berlindung, bersarang, dan mencari makan sehingga penghijauan sangat penting untuk kelangsungan hidup burung. 
Humaini, dkk (2009) menegaskan bahwa kondisi ekosistem alami yang terus mengalami tekanan sehingga perlu segera dilakukan upaya-upaya konservasi. Fungsi konservasi yaitu sebagai perlindungan sistem penyangga kehidupan, pengawasan keanekaragaman jenis tumbuhan dan satwa liar beserta ekosistemnya (Sawitri dan Iskandar, 2009).

\section{Faktor penyebab gangguan pada satwa burung}

Taman Wisata Alam (TWA) Wera merupakan hutan sekunder yang dijadikan sebagai kawasan wisata. Secara keseluruhan jenis kegiatan wisata di TWA Wera terdapat beberapa kegiatan yang dapat menyebabkan habitat satwa menjadi terganggu seperti kegiatan wisata pendakian dan perkemahan. Semua aktifitas tersebut memberikan dampak terhadap aktifitas burung, akibatnya jenis burung yang sulit beradaptasi akan meninggalkan habitatnya sehingga sulit dijumpai pada saat pengamatan.

Adam dan Retno (2010) mengatakan bahwa jenis-jenis burung yang sangat terbatas habitatnya memiliki skala kerawanan yang lebih tinggi karena jika terjadi kerusakan terhadap habitatnya secara langsung akan menurunkan bahkan memusnahkan populasi burung tersebut. Sedangkan Swastikaningrum dkk (2012), berpendapat bahwa perubahan pada habitat dapat berarti ancaman terjadinya kerusakan habitat.

Berdasarkan hasil yang penelitian yang diperoleh dalam penelitian di TWA Wera dapat disimpulkan bahwa :

Komposisi jenis burung di TWA Wera terdiri dari 12 jenis yaitu Cekakak sungai, Kacamata laut, Burung madu sriganti, Cucak kutilang, Delimukan zamrud, Elang bondol, Burung madu hitam, Srigunting jambul rambut, Walet sapi, Walet polos, Kadalan Sulawesi dan Blibong pendeta. Dua jenis terakhir adalah burung endemik Sulawesi. Ke 12 jenis burung ini termasuk ke dalam 10 famili.

Pola penyebaran burung yang ada di kawasan TWA Wera adalah mengelompok untuk 8 jenis burung yaitu Cekakak sungai, Kacamata laut, Burung madu sriganti, Blibong pendeta, Cucak kutilang, Srigunting jambul rambut, Walet sapi dan Walet polos, sedangkan Delimukan zamrud, Elang bondol, Burung madu hitam, Kadalan Sulawesi tidak teranalisis.

\section{UCAPAN TERIMA KASIH}

Penulis mengucapkan terima kasih kepada evanjeli, manan, dan tim Komunitas Pengamat Burung (KPB) Spilornis Fakultas Kehutanan Universitas Tadulako yang telah membantu pengambilan data di lapangan. Ucapan terima kasih juga ditujukan kepada BKSDA (Balai Konservasi Sumber Daya 
Alam) Sulawesi Tengah yang telah memberikan ijin kepada penulis untuk melakukan penelitian di TWA Wera.

\section{DAFTAR PUSTAKA}

Adam M dan Retno I.P., (2010). Konservasi sumberdaya Alam Hayati di Indonesia: sebuah pengantar Badan Penerbit Universitas Diponegoro Semarang.

BKSDA Sulteng., (2010). Buku Informasi Potensi Wisata TWA Wera dan TWA Bancea. BKSDA Sulteng Palu.

Celebes Bird Club, (2006). Mengenal Burung di Taman Nasional Lore Lindu,Sulawesi Tengah. Pusat penelitian Biologi-LIPI \& Nagao Natural Enviroment Foundation (NEF), Jakarta.

Coates BJ, Bishop KD, Gardner D., (2000). Panduan Lapangan Burungburung di kawasan Wallacea (Sulawesi, Maluku dan Nusa Tenggara). Kartikasari SN, Tapilatu MD, Rini D, penerjemah; Bogor: Birdlife Indonesia Programmed dan Dove Publication. Terjemahan dari: A Guide to the Bird of Wallacea (Sulawesi, the Moluccas and the Lesser Sunda Islands, Indonesia).

del Rio PCM., (2001). The abundance of four bird guilds and their use of plant in a Mexican dry forest-oak woodland gradient in two contrasting seasons. Huitzil 2:3-14.

Holmes D. \& Phillips, K., 1989. BurungBurung di Sulawesi (terjemahan), Puslitbang Biologi LIPI, Bogor.
Howes J., Bakewell D., Noor Y.R., 2003. Panduan Studi Burung Pantai. Wetlands Internasional. Bogor.

Humaini R, Kaspul, Hardiansyah., (2009). Identifikasi Jenis dan Kelimpahan Burung Diurnal di Kawasan Wisata Hutan Lindung Gunung Gedambaan Desa Gedambaan Kecamatan Pulau Laut Utara Kabupaten Kotabaru. Jurnal Wahana-Bio Volume II.

Ihsan M., (2011). Analisis Kuantitatif Komunitas Burung di Pulau Paleng dengan Fokus Burung Gagak Banggai (Corpus unicolor). Tesis Sekolah Pascasarjana Institut Pertanian Bogor. Bogor (tidak di publikasikan).

Indriyanto., (2008). Ekologi Hutan. Bumi aksara. Jakarta.

Kartono .A. P., (2000). Teknik Inventarisasi Satwa Liar dan Habitatnya. Bogor.

Krebs CJ., (1978). The Experimental Analisis of distribution and abundance.second edition. New York: Harper \& Row Publisher.

Ludwig JA, Reynolds JF., 1988. Statistical Ecology: A primer on methods and computing. New York: John Wiley $\&$ Sons.

Mac Kinnon J. Phillips K. Van Ballen B. 1993. Burung-burung di Sumatera, Jawa, Bali dan Kalimantan (termasuk Sabah, Serawak, dan Brunei Darussalam). Puslitbang Biologi. Jakarta: LIPI.

Mallo FN., (1996). Kehidupan Burung di Lembah Palu. Study Pendahuluan Dari Hasil Pengamatan Terhadap 
Keberadaan Jenis, Kelestarian dan Kondisi Habitatnya. Palu

Nugroho MS, Sri Ningsih, Ihsan M., (2013). Keanekaragaman Jenis Burung pada Areal Dongi-Dongi di Kawasan Taman Nasional Lore Lindu.Jurusan Kehutanan, Fakultas Kehutanan Universitas Tadulako. Warta Rimba volume 1, Nomer 1. 2013.

Odum, E.P., (1993). Dasar-Dasar Ekologi. Terjemahan Samingan T. Gadjah Mada University Press. Yokyakarta.

Peterson RT., (1980). Pustaka Life. Jakarta: Tiara Pustaka.

Sawitri R. dan Iskandar S., (2009). Keragaman Jenis Burung di Taman Nasional Kepulauan Wakatobi Taman Nasional Kepulauan Seribu. Pusat Litbang Konservasi dan Rehabilitasi. Jurnal Penelitian Hutan dan Konservasi Alam. Vol 9 No 2 : 175-187.

Swastikaningrum $\mathrm{H}$, Irawan $\mathrm{B}$, Harianto S., (2012). Keanekaragaman Jenis Burung pada Berbagai Tipe Pemanfaatan Lahan di Kawasan Muara Kali Lamong Perbatasan Perbatasan Surabaya-Gresik. Program Studi S1 Biologi, Departemen Biologi. Fakultas Sains dan Teknologi, Universitas Airlangga.

Tarumingkeng RC., (1994). Dinamika populasi: Kajian Ekologi Kuantitatif. Jakarta: Pustaka Sinar Harapan.

Tebisi Y., (2013). Keanekaragaman Jenis Burung di Taman Nasional Lore
Lindu (Studi Kasus Desa Bobo) Kecamatan Palolo Kabupaten Sigi. Skripsi, Program Studi Kehutanan Jurusan Kehutanan Fakultas Kehutanan Universitas Tadulako. (tidak Dipublikasikan).

Wibowo Y., (2004). Keanekaragaman Burung di Kampus Universitas Negeri Yogyakarta. Jurusan Pendidikan Biologi FMIPA Universitas Negeri Yogyakarta.

Windharti Y, Nurdjali B, Erianto., (2013). Keanekaragaman Jenis Burung Diurnal dalam Kawasan Cagar Alam Mandor Kabupaten Landak. Fakultas Kehutanan Universitas Tanjungpura.

Wong M., (1986). Trophic organization of birds in Malaysian dipterocarp forest. Auk 103:00-116. 